\title{
Comparison of digestibility of wood pulps produced by the sulfate and TMP methods and woodchips of various botanical origins and sizes
}

\author{
Kamila Buzała • Piotr Przybysz • \\ Justyna Rosicka-Kaczmarek • Halina Kalinowska
}

Received: 16 February 2015/Accepted: 29 April 2015/Published online: 12 May 2015

(C) The Author(s) 2015. This article is published with open access at Springerlink.com

\begin{abstract}
Poplar and pine cellulosic pulps derived by the sulfate process (Kappa numbers of 15.4 and 31.4 , respectively) and a poplar thermomechanical pulp (TMP, Kappa number of 124.7) as well as 0.43-0.8 mm woodchips of various botanical origins (poplar, birch, lime, oak, beech, pine, and spruce) and poplar chips of five different average particle sizes, ranging from 1.6-2.0 to $<0.43 \mathrm{~mm}$, were digested by a commercial preparation of cellulases and xylanases (NS-22086 from Novozymes). Yields of reducing sugars derived by enzymatic hydrolysis of the poplar and pine pulps that were obtained by the sulfate method achieved 100 and $89 \%$ on a dry weight basis (52.3 and $35.9 \%$ d.w. wood, respectively) while glucose yields reached 79 and $70.7 \%$ d.w. pulp (41.3 and $28.6 \%$ d.w. wood), respectively. Enzymatic hydrolysis of the pine TMP resulted in glucose and
\end{abstract}

K. Buzała $(\square) \cdot$ P. Przybysz

Institute of Papermaking and Printing Technology, Lodz University of Technology, Wolczanska str. 223,

90-924 Lodz, Poland

e-mail: buzala.kamila@wp.pl

K. Buzała $\cdot$ H. Kalinowska

Institute of Technical Biochemistry, Lodz University of Technology, Stefanowskiego str. 4/10, 90-924 Lodz, Poland

\section{J. Rosicka-Kaczmarek}

Institute of Chemical Food Technology, Lodz University of Technology, Stefanowskiego str. 4/10, 90-924 Lodz, Poland reducing sugars yields of only 14.0 and $36.7 \%$ d.w. pulp (around 13 and $34 \%$ d.w. wood, respectively). Yields of glucose and soluble reducing sugars released from the poplar chips were inversely proportional to their size and varied between around 5.3-7.8, and 15.7-22.4\% d.w., respectively. Reducing sugars yields from beech, birch and lime chips were slightly higher than from the poplar chips of the same size while pine, spruce and oak chips were less susceptible to enzymatic digestion. The dominating sugars in the hydrolysates of woodchips were glucose and cellobiose (70-90\% w/w of the sum of 5 detected sugars) while mannose, xylose and arabinose concentrations were relatively low.

Keywords Woodchips · Pulps · Digestibility · Enzymatic hydrolysis $\cdot$ Cellulases $\cdot$ Xylanases

\section{Introduction}

A sustainable production of biofuels and valuable chemicals from renewable lignocellulosic biomass has been considered a safe and ethical alternative to consumption of fossil resources that will be soon exhausted. To enhance the recovery of monosaccharides from cellulose and hemicelluloses that are coated by lignin, a variety of biomass disintegration and pretreatment methods have been developed (Chaturvedi and Verma 2013). All of them require a substantial energy input and their costs strongly affect 
the economy of plant biomass conversion. Furthermore, the harsh thermal pretreatment leads to losses in sugars and generates fermentation inhibitors like furfural, 5-hydroxymethylfurfural (5HMF), and phenolic acids (Stoutenburg et al. 2011). These harmful compounds, reducing productivity of fermentation processes, need to be removed from biomass hydrolysates that increases overall costs of lignocellulose conversions. Recent advances in production and engineering of enzymes that cleave cellulose (Wilson 2009) and hemicelluloses (Van Dyk and Pletschke 2012) cause that enzyme-mediated processes are increasingly used for conversion of plant biomass. In contrast to cellulose, which is characterized by a highly regular structure, irrespective of its source, the structure of hemicelluloses, which are polymers of pentoses and hexoses, depends on their botanical origin. Xylose and other pentoses, derived from hemicelluloses, are usually less efficiently converted to fermentation products than glucose (Stoutenburg et al. 2011). Their content in enzymatic hydrolysates depends on conditions of biomass pretreatment. For instance, enzymatic hydrolysates of hardwood and softwood cellulosic pulps derived by kraft pulping are rich in glucose, constituting above $73 \%$ soluble sugars (Buzała et al. 2015).

In this study, we attempted to assess the digestibility of a thermomechanical pulp (TMP) and compare it with the digestibility of poplar and pine cellulosic pulps derived by the sulfate process as well as woodchips of various botanical origins and sizes. For this purpose, we estimated the digestibility of 7 different sorts of $0.43-0.8 \mathrm{~mm}$ woodchips (poplar, birch, lime, oak, beech, pine, and spruce) and determined the effect of poplar chips dimensions (from $<0.43$ to $2.0 \mathrm{~mm}$ ) on results of enzymatic digestion.

Thermomechanical pulps are made by heating woodchips with steam under high pressure, followed by mechanical disintegration. These pulps contain much more lignin than kraft pulps and their chemical composition is almost the same as that of woodchips (Ma et al. 2012). Apart from cellulose, hemicelluloses and lignin, TMPs contain proteins (Hafren 2007) and fatty acids (Fleet and Breuil 1998).

Woodchips derived in large amounts from forestry wastes represent an inexpensive and easily available source of lignocelluloses. Chipping and related mechanical methods increase the surface area of lignocellulosic materials but chips are known to be resistant to enzymatic digestion owing to the protective impact of lignin. Therefore, the energy-consuming mechanical disintegration is usually combined with chemical methods, enhancing the access of enzymes to cellulose and hemicelluloses. Because of differences in the lignin content, the digestibility of chips from various botanical sources may be different. Apart from the sort of woodchips also their dimensions may affect the availability of cellulose and hemicellulose fibers to degrading enzymes.

Average contents of the three principal polymers contained in wood of 7 selected species are shown in Table 1 (Prosiński 1984). Cellulose content varies from $49 \%$ d.w. in the lime wood to $38 \%$ d.w. in the oak wood, which is characterized by the medium level of hemicelluloses (29\% d.w.) and the high level of lignin (25\% d.w.) and other substances (8\% d.w.). The pine and spruce woods contain more lignin (28\% d.w.) than the other 5 types of wood. Softwood is in general characterized by the higher content of lignin and its more cross-linked structure than hardwood. Softwood hemicelluloses, e.g., from pine and spruce wood, are known to be rich in hexoses like mannose and galactose while hardwood hemicelluloses, e.g., from poplar, oak and birch woods, contain mainly pentoses (above $21 \%$ d.w. xylose) (Girio et al. 2010).

In this study, the hydrolysis of wood pulps and chips was mediated by a multienzyme preparation NS-22086, which contains enzymes enabling conversion of cellulose and hemicelluloses to simple sugars (Buzała et al. 2015). Our previous study showed that this preparation efficiently degraded kraft cellulosic pulps from wood (poplar, pine, beech and birch) and wheat straw as well as waste fines from paper mill. It also partly saccharified poplar woodchips $(1.2-1.6 \mathrm{~mm})$ and chopped wheat straw (the size of $6 \mathrm{~mm}$ or less).

\section{Materials and methods}

\section{Woodchips}

Poplar woodchips ( 5 different average particle sizes of $1.6-2.0,1.2-1.6,0.8-1.2,0.43-0.8 \mathrm{~mm}$, and below $0.43 \mathrm{~mm}$ ) were prepared by drilling of larger pieces of poplar wood using an electric 6388AA Skil driller (Lowe's Co., USA) equipped with a Metabo drill (Poland) no 10 (10.0 $\mathrm{mm}$ in diameter). Then the chips were sieved through a series of sieves to separate 5 
Table 1 Average chemical composition of wood from selected species (Prosiński 1984)

\begin{tabular}{lllll}
\hline Species & \multicolumn{2}{l}{$\%$ dry weight } & \\
\cline { 2 - 5 } & Cellulose & Hemicelluloses & Lignin & Other substances \\
\hline Oak (Quercus pedunculata Ehrh.) & 38 & 29 & 25 & 8 \\
Birch (Betula pendula) & 40 & 36 & 20 & 4 \\
Beech (Fagus silvatica L.) & 41 & 33 & 22 & 4 \\
Pine (Pinus silvestris L.) & 42 & 25 & 28 & 5 \\
Spruce (Picea abis Karst.) & 42 & 26 & 28 & 4 \\
Poplar (Populus tremula L.) & 44 & 32 & 21 & 4 \\
Lime (Tilia cordata L.) & 49 & 21 & 18 & 12 \\
\hline
\end{tabular}

different fractions of particles. The separated fractions were subjected to enzymatic saccharification. Chips of birch, lime, oak, beech, pine and spruce woods were obtained analogously. Only the fraction of the average particle size of $0.43-0.8 \mathrm{~mm}$ of these chips was subjected to enzymatic hydrolysis.

Kraft wood pulps

Poplar and pine cellulosic pulps were prepared by the sulfate method as described elsewhere (Buzała et al. 2015) from woodchips $(25 \mathrm{~mm} \times 15 \mathrm{~mm} \times 8 \mathrm{~mm})$, containing 7-8 \% humidity. The chips were obtained from wood after the inner and outer barks and knots were mechanically removed. The disintegrated materials were kept in hermetically closed vials to avoid any changes in the humidity before the treatment with $\mathrm{NaOH}$ and $\mathrm{Na}_{2} \mathrm{~S}$ solutions [at chips: solvent ratio of 1:4 (w/v)], which were prepared freshly before the usage. Delignification processes were conducted in $15 \mathrm{~L}$ stainless steel reactors with digital regulation and monitoring of temperature. Suspensions of woodchips were heated for $120 \mathrm{~min}$ up to $160{ }^{\circ} \mathrm{C}$, incubated at this temperature for the next $120 \mathrm{~min}$ and cooled to around $20{ }^{\circ} \mathrm{C}$ using cold tap water. The insoluble fractions were separated by filtration on Buchner funnel, washed several times with demineralized water and incubated overnight in demineralized water to remove residues of the alkali-soluble fractions. The solids were disintegrated for $3 \mathrm{~min}$ in a laboratory propeller pulp disintegrator (type R1 from Labor-Meks, Poland), and the fibers were collected by centrifuging (300 rpm, $10 \mathrm{~min}$ ) and weighed. Triplicate samples of these fibers were analyzed for the humidity and residual lignin (Kappa number) contents.

The yields of production of poplar and pine pulps were 52.3 and $40.4 \%$ of wood dry weight, respectively. Kappa numbers of these pulps were 15.4 and 31.4 , respectively.

\section{Thermomechanical pulp}

The poplar TMP was kindly supplied by one of Polish paper mills. It was produced from de-barked poplar woodchips that were steamed before two-step disintegration by grinding in disc refiners. The yield of production of this pulp was $92.8 \%$ of wood dry weight and its Kappa number was 124.7. The average weighted length of fibers contained in the TMP was around $0.88 \mathrm{~mm}$ and the content of fines fraction was around $24 \%$ d.w. TMP.

Enzyme preparation

The woodchips and pulp were treated with a commercial, industrial grade enzyme preparation NS22086, which was kindly supplied by Novozymes A/S (Denmark) and contained activities of cellulases and xylanases. Activities of these enzymes were assayed by the 3,5-dinitrosalicylic acid (DNS) method (Miller 1959) at $\mathrm{pH} 5.0$ and $50{ }^{\circ} \mathrm{C}$ for $0.5 \%$ carboxymethylcellulose (CMC) and $0.5 \%$ birch xylan, respectively (reaction time of $5 \mathrm{~min}$ ). Activities of both the glycosidases were expressed as micromoles of reducing sugars released from the polysaccharide substrates in $1 \mathrm{~min}(\mathrm{U})$. The filter paper activity was determined at $\mathrm{pH} 5.0$ and $50{ }^{\circ} \mathrm{C}$ according to Adney and Baker (2008) and expressed as FPU/ml. Total reducing sugars and glucose concentrations in NS-22086 preparation were assayed as described below.

Enzymatic hydrolysis

Batches of woodchips and pulps (around $0.3 \mathrm{~g}$ each) were suspended in $0.1 \mathrm{M}$ sodium-acetate buffer solu-

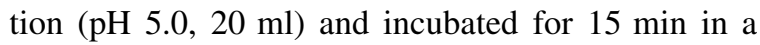
water bath at $50{ }^{\circ} \mathrm{C}$. Then $1 \mathrm{ml}$ aliquot of the NS- 
22086 (diluted sixfold in the same buffer) was added (with vigorous mixing) to each of these suspensions to initiate enzymatic digestion, which was conducted at $50{ }^{\circ} \mathrm{C}$ for $48 \mathrm{~h}$ (for the kraft pulps), $72 \mathrm{~h}$ (for the woodchips) or $96 \mathrm{~h}$ (for the TMP). The hydrolysates were sampled just after addition of the enzyme (to determine initial concentrations of glucose and total reducing sugars) and after 1, 3, 6, 24, 48, 72 and $96 \mathrm{~h}$ of the process (to estimate the progress of enzymatic hydrolysis). All samples of enzymatic hydrolysates were filtered through a medium-fast filter paper and the filtrates were subjected to analyses.

Results of enzymatic attack on wood pulp fibers were monitored using a MPI3/SK12 PZO (Poland) optical microscope (at $200 \times$ magnification). Changes in the appearance of the surface of woodchips during their enzymatic digestion were observed using an electron scanning microscope S-4700 Hitachi SEM/ EDS (at $200 \times$ magnification).

\section{Analytical methods}

Reducing sugars concentration was assayed using the alkaline DNS reagent according to Miller (1959). Mono- and disaccharide profiles of the hydrolysates were determined by HPLC using an Ultimata 3000 Dionex liquid chromatograph equipped with a Rezex RPM-Monosaccharide $\mathrm{Pb}^{2+}$ column $(8 \mu \mathrm{m}, 7.8 \times$ $300 \mathrm{~mm}$ ) and a Shodex-RI-10 refractive index detector. The temperature of the column and RI detector was $80{ }^{\circ} \mathrm{C}$ and $40{ }^{\circ} \mathrm{C}$, respectively. Samples of hydrolysates were filtered through a nylon syringe filter $(0.45 \mu \mathrm{m})$ before HPLC analysis. The volume of injected samples was $10 \mu \mathrm{l}$. HPLC grade water (Sigma) was used as the mobile phase at a flow rate of $0.6 \mathrm{ml} / \mathrm{min}$. Results of sugar resolution were recorded over $35 \mathrm{~min}$. Glucose concentration was also determined according to Barham and Trinder (1972), using a commercial diagnostic kit employing glucose oxidase and peroxidase (Biomaxima, Poland).

Both hydrolysis processes and analyses of the hydrolysates were carried out in at least triplicate. Their results are presented as mean \pm standard deviation (SD).

\section{Yield calculations}

The yield of glucose and total reducing sugars were calculated according to Kumar and Wyman (2009) with some modification:
Glucose yield $=$ Glucose in hydrolysate $(\mathrm{g})$ $\times 0.9$ /nitial dry weight of the sample $(\mathrm{g})$

Total reducing sugars yield

$=$ Reducing sugars in hydrolysate $\times 0.9 /$ Initial dry weight of the sample $(\mathrm{g})$

The same coefficient (0.9) was used in the calculations for all the reducing sugars quantified by HPLC because glucose was the dominating of them.

\section{Results and discussion}

The multienzyme preparation NS-22086, which was used in this study for digestion of the woodchips, kraft pulps and TMP, was selected as described by Buzała et al. (2015). It displays activities of cellulases and xylanases, which at $\mathrm{pH} 5.0$ and temperature of $50{ }^{\circ} \mathrm{C}$ equaled 80.6 (for CMC) and $192.5 \mathrm{U} / \mathrm{ml}$, respectively. The filter paper activity of this preparation was 112.12 FPU/ml. Like many other enzyme preparations it contains soluble reducing sugars $(68.6 \mathrm{mg} / \mathrm{ml})$ including free glucose $(42.0 \mathrm{mg} / \mathrm{ml}, 61.22 \%$ total reducing sugars). Amounts of sugars that were contained in NS22086 preparation were discounted when yields of enzymatic saccharification of the substrates were calculated. To reduce amounts of sugars added into reaction mixtures with NS-22086 preparation, it was diluted sixfold before hydrolysis processes that were carried out at enzyme: substrate ratio of around 13.43 U: $0.3 \mathrm{~g}$ dry weight (18.69 FPU: $0.3 \mathrm{~g}$ d.w.) for cellulases, and around $32.08 \mathrm{U}: 0.3 \mathrm{~g}$ d.w. for xylanases.

The effect of lignin content in wood pulps on enzymatic saccharification yield

Yields of reducing sugars released in $48 \mathrm{~h}$ by the preparation NS-22086 from the poplar and pine pulps (Kappa numbers of 15.4 and 31.4, respectively) and TMP (Kappa number of 124.7) depended on the content of lignin in these substrates (Table 2). Amounts of reducing sugars obtained from the pine pulp were lower than from the poplar pulp (88.9 and $100 \%$ d.w. pulp, and 39.5 and $52.3 \%$ d.w. wood, respectively) like glucose yields (70.7 and $79.0 \%$ d.w. pulp, and 28.6 and $41.3 \%$ d.w. wood, respectively) 
Table 2 Concentrations and yields of glucose and total reducing sugars in enzymatic hydrolysates of $\mathrm{TMP}\left(50{ }^{\circ} \mathrm{C}\right.$, pH $5.0,48$ and $72 \mathrm{~h})$ and kraft pulps $\left(50^{\circ} \mathrm{C}, \mathrm{pH} 5.0,48 \mathrm{~h}\right)$

\begin{tabular}{|c|c|c|c|c|c|c|}
\hline \multirow[t]{2}{*}{ Substrate } & \multirow{2}{*}{$\begin{array}{l}\text { Glucose } \\
\text { concentration } \\
(\mathrm{mg} / \mathrm{ml})\end{array}$} & \multicolumn{2}{|c|}{ Mean glucose yield } & \multirow{2}{*}{$\begin{array}{l}\text { Total reducing } \\
\text { sugars concentration } \\
(\mathrm{mg} / \mathrm{ml})\end{array}$} & \multicolumn{2}{|c|}{ Mean reducing sugars yield } \\
\hline & & $\%$ d.w. pulp & $\%$ d.w. wood & & $\%$ d.w. pulp & $\%$ d.w. wood \\
\hline TMP (48 h) & $1.87 \pm 0.02$ & 9.79 & 9.15 & $4.65 \pm 0.02$ & 25.58 & 23.91 \\
\hline TMP (72 h) & $2.54 \pm 0.02$ & 14.04 & 13.03 & $6.31 \pm 0.03$ & 36.69 & 34.05 \\
\hline Poplar pulp (Kappa 15.4) & $12.67 \pm 0.15$ & 79.00 & 41.30 & $16.51 \pm 0.18$ & 100.00 & 52.30 \\
\hline Pine pulp (Kappa 31.4) & $11.41 \pm 0.23$ & 70.72 & 28.57 & $14.47 \pm 1.65$ & 88.92 & 35.90 \\
\hline
\end{tabular}

Results are shown as means of triplicate assays \pm SD. Amounts of glucose and other reducing sugars contained in NS-22086 preparation were subtracted to calculate yields of sugars released from the chips

Table 3 Mean percentages of glucose, cellobiose, xylose, arabinose and mannose among mono- and disaccharides contained in hydrolysates of TMP and poplar and pine kraft pulps

\begin{tabular}{llllll}
\hline Substrate & $\%$ w/w & & & \\
\cline { 2 - 6 } & Glucose & Cellobiose & Xylose & Mannose & Arabinose \\
\hline TMP & 40.23 & 45.86 & n.d. & n.d. & 10.91 \\
Poplar pulp (Kappa 15.4) & 76.74 & 10.37 & 12.71 & 0.18 & n.d. \\
Pine pulp (Kappa 31.4) & 78.88 & 12.54 & 3.45 & 1.54 & 3.59 \\
\hline
\end{tabular}

n.d. not detected

that was correlated with around twice higher value of Kappa number of the pine pulp. Because of the high lignin concentration in the TMP (Kappa number of the latter pulp was 8.1-fold higher than that of the poplar kraft pulp) yields of glucose and total reducing sugars were relatively low (around 14 and $36.7 \%$ d.w. TMP and 13 and $34 \%$ d.w. wood). Thus the 8.1-fold increase in the Kappa number of the poplar pulp caused about 3.2 and 1.5-fold decrease in glucose and total reducing sugars yields.

Mono- and disaccharide profiles of enzymatic hydrolysates of the three pulps, which were determined by HPLC, are shown in Table 3. Glucose accounted for $76.7-78.9 \% \mathrm{w} / \mathrm{w}$ of the sum of five identified sugars in the hydrolysates of the two kraft pulps. Its concentration in the TMP hydrolysate was almost twice lower (around $40 \% \mathrm{w} / \mathrm{w}$ ), after both 48 and $96 \mathrm{~h}$ of the hydrolysis, and the dominating sugar was cellobiose (around $46 \% \mathrm{w} / \mathrm{w}$ ) that may suggest inhibition of $\beta$-glucosidase activity contained in NS22086 preparation. Inhibition of $\beta$-glucosidase is usually caused by glucose released by enzymes from plant biomass (Andrić et al. 2010). However, glucose concentration in the hydrolysate of TMP (around $1.9 \mathrm{mg} / \mathrm{ml}$ after $48 \mathrm{~h}$ and $2.5 \mathrm{mg} / \mathrm{ml}$ after $96 \mathrm{~h}$ ) was around fivefold lower than in the hydrolysates of the two kraft pulps (around $12 \mathrm{mg} / \mathrm{ml}$ ) that suggests other causes of the high cellobiose levels. Putative $\beta$ glucosidase inhibitors were residual lignin and extractives remained after the thermomechanical processing of poplar wood. Another difference between the hydrolysate of TMP and the other two digests was the high level of arabinose (almost $11 \% \mathrm{w} / \mathrm{w}$ ) and the lack of xylose and mannose. Digests of the poplar kraft pulp did not contain arabinose, contained minor amounts of mannose (about $0.2 \% \mathrm{w} / \mathrm{w}$ ) but were rich xylose (about $13 \% \mathrm{w} / \mathrm{w}$ ). Xylose and arabinose contents in the hydrolysates of pine kraft pulp were around $3.5 \%(\mathrm{w} / \mathrm{w})$ while mannose contents were around twice lower (around $1.5 \% \mathrm{w} / \mathrm{w}$ ).

The course of the poplar kraft pulp degradation by enzymes was also observed under the optical microscope (Fig. 1). Only residues of fibers were visible after $24 \mathrm{~h}$ of this process. 
Relationship between the size of poplar woodchips and enzymatic saccharification yield

Owing to differences in glucose and other reducing sugars yields from enzymatic hydrolysis of the poplar kraft and TMPs, also poplar woodchips that were used to produce these pulps were treated with NS-22086 multienzyme preparation. The relationship between the size of poplar woodchips and dynamics of their degradation, presented as a rise in glucose yields (percentage of free glucose derived from $1 \mathrm{~g} \mathrm{~d}$.w. of the chips), is shown in Fig. 2. Despite the relatively low dynamics of enzymatic hydrolysis of the poplar chips, the impact of their dimensions on the rate of this process was observed already after the first hour because the yield of glucose released from the smallest chips was more than twice higher compared to the largest chips (0.72 and $0.3 \%$ d.w., respectively). Concentrations and yields of free glucose and other reducing sugars after 48 and $72 \mathrm{~h}$ of the hydrolysis (Table 4) were inversely proportional to the size of polar woodchips. Comparison of the results obtained after 48 and $72 \mathrm{~h}$ showed that the process ran very slowly for the last $24 \mathrm{~h}$. Ultimately, digestion of the smallest chips produced $45 \%$ more glucose (7.75 vs. $5.33 \%$ d.w.) and $43 \%$ more total reducing sugars (22.39 and $15.69 \%$ d.w., respectively) compared to the largest chips. It means that the around fourfold decrease in dimensions of poplar chips caused only around $43-45 \%$ increase in the degree of their conversion to glucose and other reducing sugars.

HPLC analysis of enzymatic hydrolysates obtained after 48 and $72 \mathrm{~h}$ digestion of the poplar woodchips of various sizes showed that percentages of 5 detected sugars were not significantly changed for the last $24 \mathrm{~h}$ of the process. Glucose content in these hydrolysates was around $38-41 \%$ of the sum of the detected sugars (Table 5). Concentrations of its reducing dimer-cellobiose were 6-16\% higher (around 43-59\% w/w) while contents of xylose (around 1.2-10\% w/w), mannose (around $1.2-6.3 \% \mathrm{w} / \mathrm{w}$ ) and arabinose (detected only in the hydrolysates of the smallest chips-around $7 \%$ w/w) were considerably lower. This profile of sugars is thought to be a consequence of a relatively high activity of cellobiohydrolase contained in the preparation NS-22086 and inhibition of $\beta$-glucosidase despite very low glucose concentrations in all these hydrolysates (up to around $1.5 \mathrm{mg} / \mathrm{ml}$ ).
The size of the smallest poplar woodchips (below $0.43 \mathrm{~mm}$ ) was alike the size of sawdust particles. Sawdust is a by-product of wood processing (Liu et al. 2014). It is generated in large amounts and used to produce charcoal, to absorb toxic compounds and as a filler in plastics and paperboard etc. Although it is flammable and furthermore, cellulose contained in pine wood dust was found to be an agent causing pulmonary inflammation and fibrosis, sawdust represents a potential raw material for biorefineries. Our results demonstrate that despite the large surface area it requires delignification before enzymatic hydrolysis.

The interplay between botanical origin of woodchips and hydrolysis efficiency

Comparison of glucose and total reducing sugars yields derived from the $0.43-0.8 \mathrm{~mm}$ poplar chips (7.47\% d.w. and $19.47 \%$ d.w., respectively) with those of the other woodchips of the same size showed that the beech and birch ones were more susceptible to enzymatic digestion (reducing sugars yields of 26.63 and $26.19 \%$ d.w., respectively) while the pine, spruce and oak chips were more recalcitrant (yields of 17.36, 14.23 and $5.61 \%$ d.w., respectively) (Table 6). Comparison of the results obtained after 48 and $72 \mathrm{~h}$ enzymatic treatment of all these chips indicates that the increase in glucose and other reducing sugars yields was very low during the last $24 \mathrm{~h}$. The ultimate total reducing sugars yields from the poplar and lime woodchips were comparable (19.47 and $21.48 \%$ d.w., respectively). Also glucose yields from these chips were alike (7.47 and $6.24 \%$ d.w., respectively).

Changes in the appearance of the surface of birch chips, which underwent saccharification in around $26 \%$, were visible under the electron scanning microscope (Fig. 3). The size of indentations in their surface, caused by the attack of enzymes on accessible polysaccharide fibers, gradually grew with time.

Mono- and disaccharide profiles of the hydrolysates derived from the examined woodchips depended on their botanical origin (Table 7). They were exactly the same after 48 and $72 \mathrm{~h}$ of hydrolysis. Hydrolysates of beech, birch, lime and oak chips were rich in mannose (22-29\% w/w of the sum of 4 identified sugars). Its contents in the hydrolysates of pine and spruce chips were around threefold lesser while in case of the poplar chips-even fivefold smaller. Xylose contents 

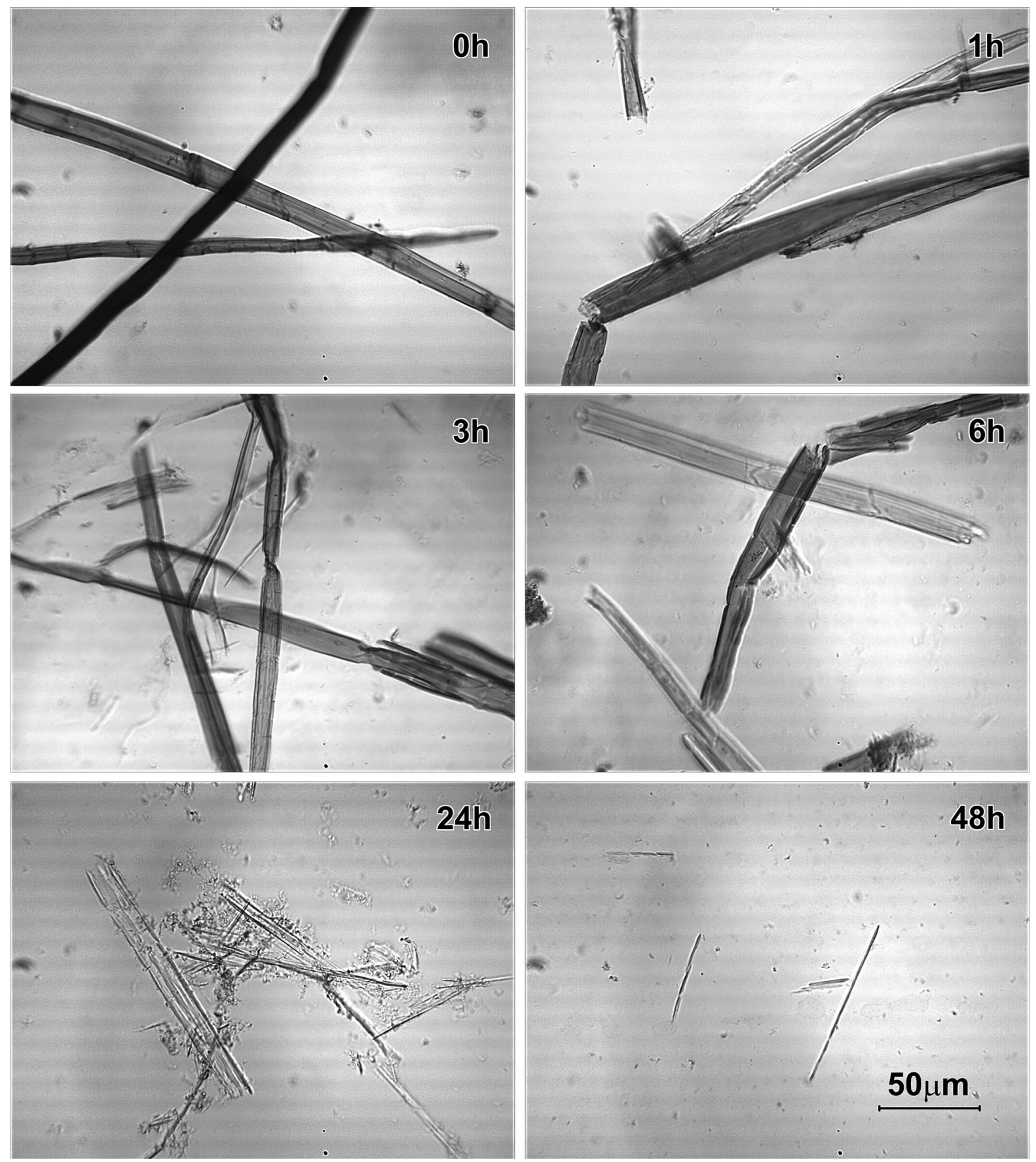

Fig. 1 Microscopic images at $\times 200$ magnification showing the course of poplar cellulosic pulp hydrolysis by NS-22086 preparation $\left(50{ }^{\circ} \mathrm{C}, \mathrm{pH} 5.0,0-48 \mathrm{~h}\right)$

in the hydrolysates varied from around 0.3 to $3.7 \%$ (w/w) of the sum of sugars and was the highest in the hydrolysate of birch chips. Irrespective of wood species, the dominating simple sugar in the hydrolysates was glucose (around 27-45\% w/w), which along with its dimer, cellobiose (25-64\% w/w), accounted for around 70-94\% w/w of the sum of 4 sugars. The high content of cellobiose, which is 
Fig. 2 Dependence of glucose yields on the size of poplar woodchips treated with NS-22086 preparation

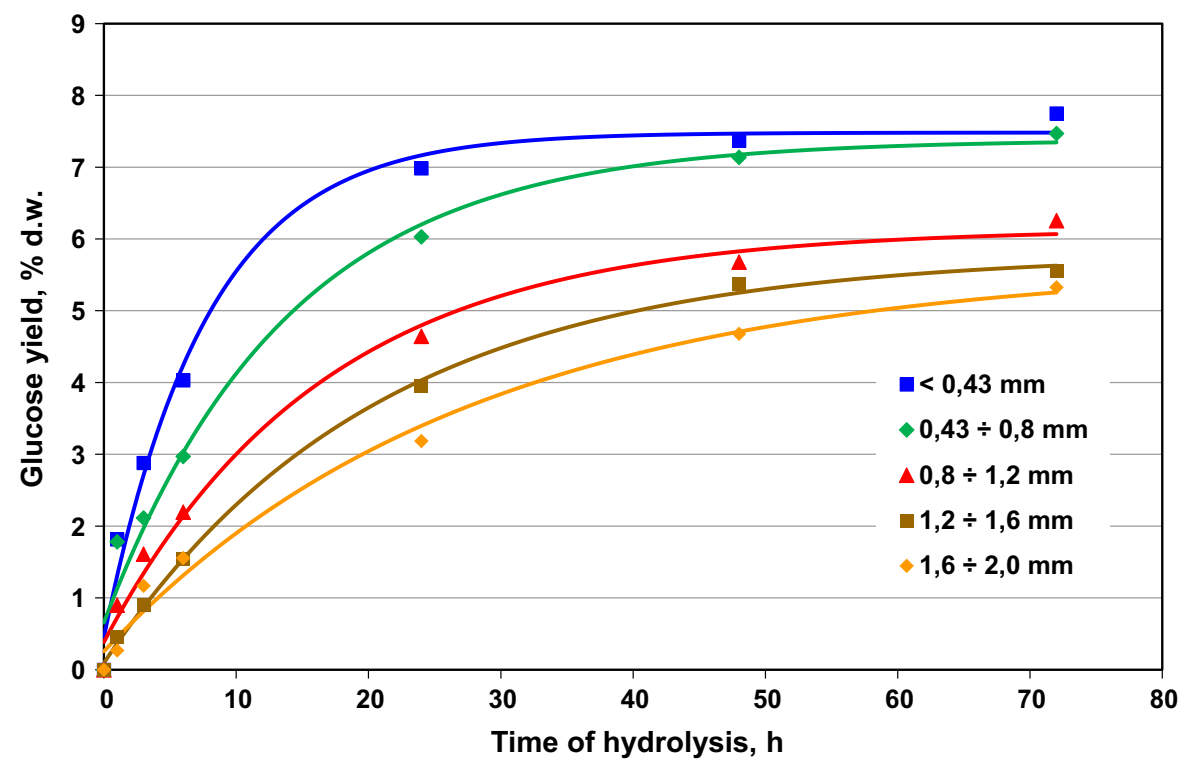

Table 4 Concentrations and yields (on a dry weight basis) of free glucose and total reducing sugars in enzymatic hydrolysates of poplar woodchips of various sizes $\left(50{ }^{\circ} \mathrm{C}, \mathrm{pH} 5.0,48\right.$ and $\left.72 \mathrm{~h}\right)$

\begin{tabular}{|c|c|c|c|c|c|c|c|c|}
\hline \multirow[t]{2}{*}{$\begin{array}{l}\text { The size of poplar } \\
\text { woodchips (mm) }\end{array}$} & \multicolumn{2}{|c|}{$\begin{array}{l}\text { Glucose concentration } \\
(\mathrm{mg} / \mathrm{ml})\end{array}$} & \multicolumn{2}{|c|}{$\begin{array}{l}\text { Mean } \\
\text { glucose yield } \\
(\% \text { d.w. })\end{array}$} & \multicolumn{2}{|c|}{$\begin{array}{l}\text { Total reducing sugars } \\
\text { concentration } \\
(\mathrm{mg} / \mathrm{ml})\end{array}$} & \multicolumn{2}{|c|}{$\begin{array}{l}\text { Mean reducing } \\
\text { sugars yield } \\
\text { (\% d.w.) }\end{array}$} \\
\hline & $48 \mathrm{~h}$ & $72 \mathrm{~h}$ & $48 \mathrm{~h}$ & $72 \mathrm{~h}$ & $48 \mathrm{~h}$ & $72 \mathrm{~h}$ & $48 \mathrm{~h}$ & $72 \mathrm{~h}$ \\
\hline $1.6-2.0$ & $1.04 \pm 0.06$ & $1.14 \pm 0.15$ & 4.68 & 5.33 & $2.70 \pm 0.33$ & $2.96 \pm 0.41$ & 13.78 & 15.69 \\
\hline $1.2-1.6$ & $1.15 \pm 0.08$ & $1.18 \pm 0.06$ & 5.37 & 5.56 & $2.92 \pm 0.11$ & $3.00 \pm 0.16$ & 15.35 & 15.89 \\
\hline $0.8-1.2$ & $1.19 \pm 0.06$ & $1.28 \pm 0.04$ & 5.68 & 6.26 & $3.04 \pm 0.08$ & $3.27 \pm 0.10$ & 15.96 & 17.59 \\
\hline $0.43-0.8$ & $1.38 \pm 0.11$ & $1.43 \pm 0.17$ & 7.14 & 7.47 & $3.37 \pm 0.20$ & $3.49 \pm 0.41$ & 18.61 & 19.47 \\
\hline Below 0.43 & $1.46 \pm 0.12$ & $1.52 \pm 0.02$ & 7.37 & 7.75 & $3.88 \pm 0.10$ & $4.04 \pm 0.06$ & 21.29 & 22.39 \\
\hline
\end{tabular}

Results are shown as means of triplicate assays \pm SD. Amounts of glucose and other reducing sugars contained in NS-22086 preparation were subtracted to calculate yields of sugars released from the chips

Table 5 Mean percentages of glucose, cellobiose, xylose, mannose and arabinose among mono- and disaccharides contained in $72 \mathrm{~h}$ hydrolysates of the poplar woodchips of various sizes

\begin{tabular}{|c|c|c|c|c|c|}
\hline \multirow{2}{*}{$\begin{array}{l}\text { Poplar woodchips size } \\
(\mathrm{mm})\end{array}$} & \multicolumn{5}{|l|}{$\% \mathrm{w} / \mathrm{w}$} \\
\hline & Glucose & Cellobiose & Xylose & Mannose & Arabinose \\
\hline $1.6-2.0$ & 38.45 & 58.85 & 1.49 & 1.20 & n.d. \\
\hline $1.2-1.6$ & 39.36 & 57.61 & 1.46 & 1.58 & n.d. \\
\hline $0.8-1.2$ & 39.24 & 53.22 & 1.21 & 6.33 & n.d. \\
\hline $0.43-0.8$ & 40.99 & 52.24 & 1.83 & 4.94 & n.d. \\
\hline Below 0.43 & 37.60 & 43.47 & 9.74 & 2.31 & 6.88 \\
\hline
\end{tabular}

n.d. not detected 
Table 6 Concentrations and yields of total reducing sugars and free glucose in enzymatic hydrolysates of $0.43-0.8$ mm woodchips of various botanical origins $\left(50^{\circ} \mathrm{C}, \mathrm{pH} 5.0,48\right.$ and $72 \mathrm{~h}$ )

\begin{tabular}{|c|c|c|c|c|c|c|c|c|}
\hline \multirow[t]{2}{*}{ Type of wood } & \multicolumn{2}{|c|}{$\begin{array}{l}\text { Glucose concentration } \\
(\mathrm{mg} / \mathrm{ml})\end{array}$} & \multicolumn{2}{|c|}{$\begin{array}{l}\text { Mean glucose } \\
\text { yield (\% d.w.) }\end{array}$} & \multicolumn{2}{|c|}{$\begin{array}{l}\text { Total reducing sugars } \\
\text { concentration }(\mathrm{mg} / \mathrm{ml})\end{array}$} & \multicolumn{2}{|c|}{$\begin{array}{l}\text { Mean reducing sugars } \\
\text { yield ( } \% \text { d.w.) }\end{array}$} \\
\hline & $48 \mathrm{~h}$ & $72 \mathrm{~h}$ & $48 \mathrm{~h}$ & $72 \mathrm{~h}$ & $48 \mathrm{~h}$ & $72 \mathrm{~h}$ & $48 \mathrm{~h}$ & $72 \mathrm{~h}$ \\
\hline Poplar & $1.38 \pm 0.02$ & $1.43 \pm 0.17$ & 7.14 & 7.47 & 3.37 & $3.49 \pm 0.41$ & 18.61 & 19.47 \\
\hline Beech & $1.95 \pm 0.06$ & $2.09 \pm 0.09$ & 10.55 & 11.42 & 4.32 & $4.63 \pm 0.02$ & 24.60 & 26.63 \\
\hline Birch & $1.61 \pm 0.07$ & $1.84 \pm 0.04$ & 8.48 & 10.01 & 3.32 & $4.48 \pm 0.09$ & 22.19 & 26.19 \\
\hline Lime & $1.10 \pm 0.01$ & $1.29 \pm 0.01$ & 5.63 & 6.24 & 3.27 & $3.84 \pm 0.04$ & 19.38 & 21.48 \\
\hline Oak & $0.44 \pm 0.01$ & $0.52 \pm 0.01$ & 2.49 & 2.91 & 1.18 & $1.39 \pm 0.02$ & 4.80 & 5.61 \\
\hline Pine & $0.81 \pm 0.02$ & $0.82 \pm 0.01$ & 3.25 & 3.37 & 3.03 & $3.07 \pm 0.05$ & 16.74 & 17.36 \\
\hline Spruce & $0.78 \pm 0.02$ & $0.81 \pm 0.01$ & 2.87 & 3.09 & 2.65 & $2.75 \pm 0.01$ & 13.22 & 14.23 \\
\hline
\end{tabular}

Results are shown as means of triplicate assays \pm SD. Amounts of glucose and other reducing sugars contained in NS-22086 preparation were subtracted to calculate yields of sugars released from the chips
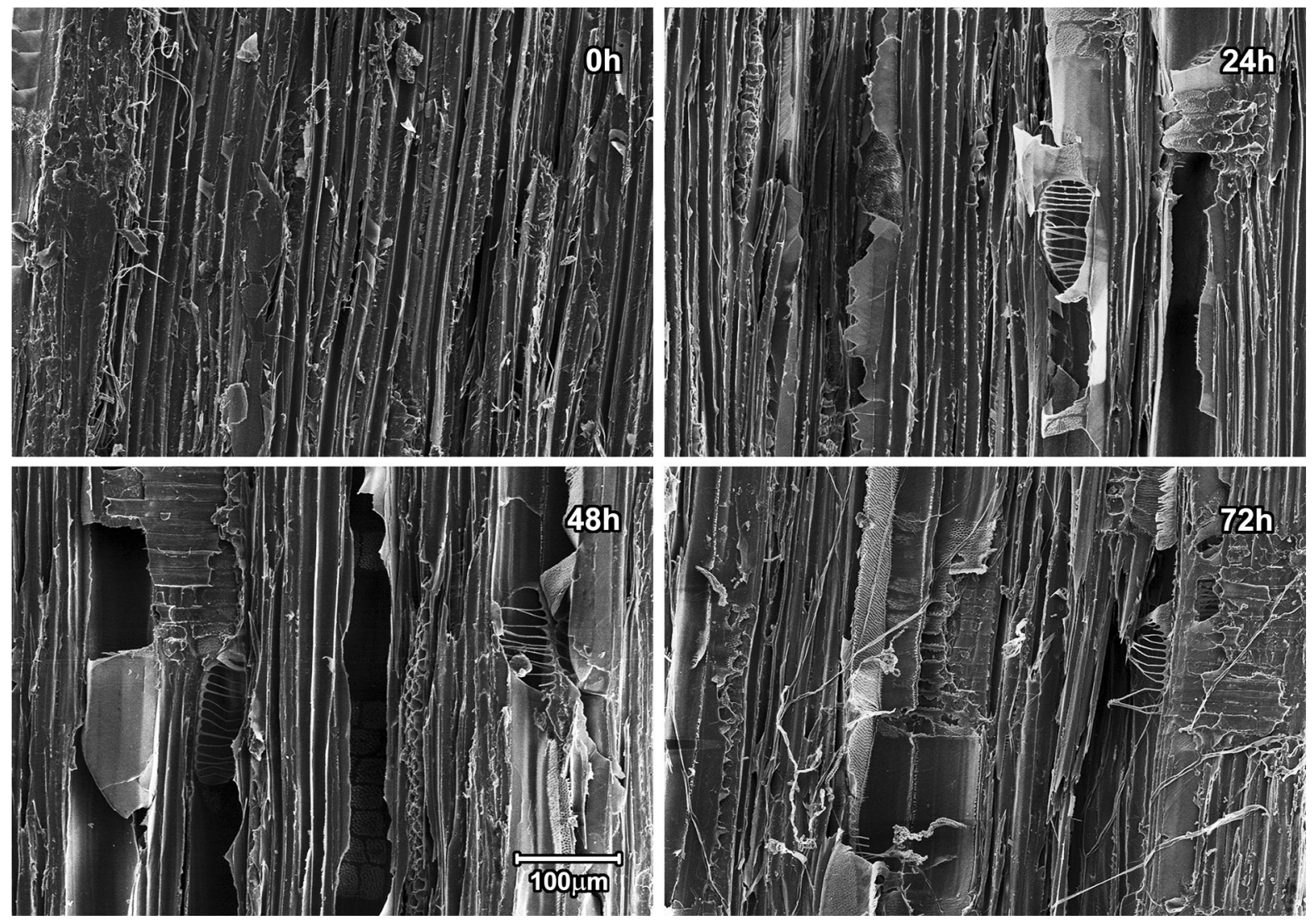

Fig. 3 Microscopic images (electron microscope, $\times 200$ magnification) showing digestion of birch chips by NS-22086 preparation $\left(50{ }^{\circ} \mathrm{C}, \mathrm{pH} 5.0,0-72 \mathrm{~h}\right)$

released from ends of accessible cellulose chains by cellobiohydrolase and which should be cleaved to glucose by $\beta$-glucosidase, suggests inhibition of the latter enzyme despite very low glucose concentrations in all these hydrolysates (up to around $2 \mathrm{mg} / \mathrm{ml}$ ). Arabinose was not detected in these hydrolysates 
Table 7 Percentages of glucose, cellobiose, xylose and mannose among mono- and disaccharides contained in $72 \mathrm{~h}$ hydrolysates of the $0.43-0.8 \mathrm{~mm}$ woodchips of various botanical origins

\begin{tabular}{llllc}
\hline \multirow{2}{*}{ Type of wood } & \multicolumn{3}{l}{ w/w } & \\
\cline { 2 - 5 } & Glucose & Cellobiose & Xylose & Mannose \\
\hline Poplar & 40.99 & 52.24 & 1.83 & 4.94 \\
Beech & 45.09 & 25.60 & 0.51 & 28.80 \\
Birch & 41.06 & 32.08 & 3.65 & 23.21 \\
Lime & 33.66 & 42.99 & 1.00 & 22.36 \\
Oak & 37.41 & 38.46 & 0.68 & 23.46 \\
Pine & 26.68 & 64.08 & 0.44 & 8.81 \\
Spruce & 29.52 & 61.46 & 0.29 & 8.72 \\
\hline
\end{tabular}

although it appeared in hydrolysates of the smallest poplar chips (Table 5).

\section{Conclusions}

Effects of lignin content in wood pulps as well as size and botanical origin of woodchips on efficiency of their digestion by cellulases and hemicellulases were determined. The highest glucose and total reducing sugars yields were obtained from the poplar kraft pulp (around 79 and $100 \%$ d.w. pulp, 41.3 and $52.3 \%$ d.w. wood, respectively), which had the lowest Kappa number (15.4) among substrates used in this study. The yields of the same products from the pine kraft pulp (around twice higher Kappa number of 31.4) were approximately $10 \%$ lower. Glucose and reducing sugars yields derived by twice longer enzymatic digestion of the poplar TMP (Kappa number of 124.7) were only around 14 and $34 \%$ d.w. (around 13 and $34 \%$ d.w. wood), respectively. Thus despite much higher yield of the latter pulp (92.8\% d.w. wood) compared to the kraft pulps (52.3 and $40.4 \%$ d.w. wood for the poplar and pine kraft pulps, respectively) its enzymatic saccharification gave around threefold less glucose on a poplar wood dry weight basis. However, amounts of glucose and other reducing sugars derived from the poplar TMP were higher compared to those derived from unprocessed woodchips. Thermomechanical processing apparently made poplar wood more susceptible to enzymatic degradation. The hydrolysates of TMP were rich in cellobiose like the hydrolysates of all woodchips (above $45 \%$ w/w of identified sugars, with an exception of birch, beech and oak digests, containing 25-38\% w/w cellobiose). The second dominating sugar was glucose $(26-40 \% \mathrm{w} / \mathrm{w})$. The hydrolysates of beech, lime, birch and oak chips were rich in mannose (22-29\% w/w) like the hydrolysates of the largest poplar chips (around $6 \% \mathrm{w} / \mathrm{w}$ ). The TMP hydrolysate was rich in arabinose (around $11 \% \mathrm{w} / \mathrm{w}$ ) in contrast to the hydrolysate of the poplar kraft pulp, which was rich in xylose (around $13 \% \mathrm{w} / \mathrm{w}$ ). The other hydrolysates contained relatively small amounts of xylose and arabinose (or did not contain these pentoses). Reducing sugars yields from poplar woodchips with dimensions ranging from 1.6 to 2.0 to $<0.43 \mathrm{~mm}$ varied from around 15.7 to $22.4 \%$ d.w., respectively, while glucose yields ranged from around 5.3 to $7.8 \%$ d.w., respectively. Thus the energy-consuming mechanical disintegration of woodchips had a relatively weak impact on the efficiency of their saccharification by cellulases and hemicellulases. The poplar chips $(0.43-0.8 \mathrm{~mm})$ were slightly less susceptible to enzymatic attack than the beech, birch and lime chips of the same size and more susceptible than the pine, spruce and oak chips. Thus the preparation NS-22086 more efficiently degraded hardwood (with an exception of oak) than the softwood chips.

Acknowledgments Part of the research was financially supported by project N N309 706340 funded by National Science Centre (NCN, Poland) and by project PBS1/A8/16/ 2013 funded by National Centre for Research and Development (NCBiR, Poland). The authors are also grateful to Mrs. Katarzyna Kowal for her support in the elaboration of experimental data.

Open Access This article is distributed under the terms of the Creative Commons Attribution 4.0 International License (http:// creativecommons.org/licenses/by/4.0/), which permits unrestricted use, distribution, and reproduction in any medium, provided you give appropriate credit to the original author(s) and the source, provide a link to the Creative Commons license, and indicate if changes were made.

\section{References}

Adney B, Baker J (2008) Measurements of cellulase activities. NREL/TP-510-42628

Andrić P, Meyer AS, Jensen PA, Dam-Johansen K (2010) Reactor design for minimizing product inhibition during enzymatic lignocellulose hydrolysis: I. Significance and mechanism of cellobiose and glucose inhibition on cellulolytic enzymes. Biotechnol Adv 28:308-324 
Barham D, Trinder P (1972) An improved color reagent for the determination of blood glucose by the oxidase system. Analyst 97:142-145

Buzała K, Przybysz P, Rosicka-Kaczmarek J, Kalinowska H (2015) Production of glucose-rich enzymatic hydrolysates from cellulosic pulps. Cellulose 22:663-674

Chaturvedi V, Verma P (2013) An overview of key pretreatment processes employed for bioconversion of lignocellulosic biomass into biofuels and value added products. 3 Biotech 3:415-431

Fleet C, Breuil C (1998) High concentrations of fatty acids affect the lipase treatment of softwood thermomechanical pulp. Appl Microbiol Biotechnol 49:517-522

Girio FM, Fonseca C, Carvalheiro F, Duarte LC, Marques S, Bogel-Łukasik R (2010) Hemicelluloses for fuel ethanol: a review. Bioresour Technol 101:4775-4800

Hafren J (2007) Proteins in Norway spruce thermomechanical pulp. J Wood Sci 53:143-146

Kumar R, Wyman CE (2009) Effects of cellulase and xylanase enzymes on the deconstruction of solids from pretreatment of poplar by leading technologies. Biotechnol Prog 25:302-314

Liu J, Korpinen R, Mikkonen KS, Willfor S, Xu C (2014) Nanofibrillated cellulose originated from birch sawdust after sequential extractions: a promising polymeric material from waste to films. Cellulose 21:2587-2598

Ma P, Fu S, Zhai H, Law K, Daneault C (2012) Influence of TEMPO-mediated oxidation on the lignin of thermomechanical pulp. Bioresour Technol 118:607-610

Miller GL (1959) Use of dinitrosalicylic acid reagent for determination of reducing sugar. Anal Chem 31:426-428

Prosiński S (1984) In: Chemistry of wood, National Agricultural and Forestry Publishing Office, Warsaw ISBN 83-0900674-8, pp. 56-57

Stoutenburg RM, Perrotta JA, Nakas JP (2011) Overcoming inhibitors in a hemicellulosic hydrolysate: improving fermentability by feedstock detoxification and adaptation of Pichia stipitis. J Ind Microbiol Biotechnol 38:1939-1945

Van Dyk JS, Pletschke BI (2012) A review of lignocellulose bioconversion using enzymatic hydrolysis and synergistic cooperation between enzymes-Factors affecting enzymes, conversion and synergy. Biotechnol Adv 30:1458-1480

Wilson DB (2009) Cellulases and biofuels. Curr Opin Biotechnol 20:295-299 